University of South Florida

DIGITAL COMMONS

@ UNIVERSITY OF SOUTH FLORIDA
Digital Commons @ University of

South Florida

6-1-2011

\title{
Florida Bus Maintenance Staffing Practices
}

CUTR

Follow this and additional works at: https://digitalcommons.usf.edu/cutr_nctr

\section{Recommended Citation}

"Florida Bus Maintenance Staffing Practices," National Center for Transit Research (NCTR) Report No. CUTR-NCTR-RR-2010-03, Center for Urban Transportation Research, University of South Florida, 2011. DOI: https://doi.org/10.5038/CUTR-NCTR-RR-2010-03

Available at: https://scholarcommons.usf.edu/cutr_nctr/128

This Technical Report is brought to you for free and open access by the National Center for Transit Research (NCTR) Archive (2000-2020) at Digital Commons @ University of South Florida. It has been accepted for inclusion in Research Reports by an authorized administrator of Digital Commons @ University of South Florida. For more information, please contact digitalcommons@usf.edu. 
National Center

for Transit Research

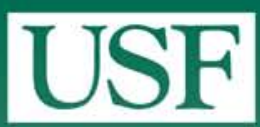

UNIVERSITY OF

SOUTH FLORIDA

\section{Florida Bus Maintenance Staffing Practices}

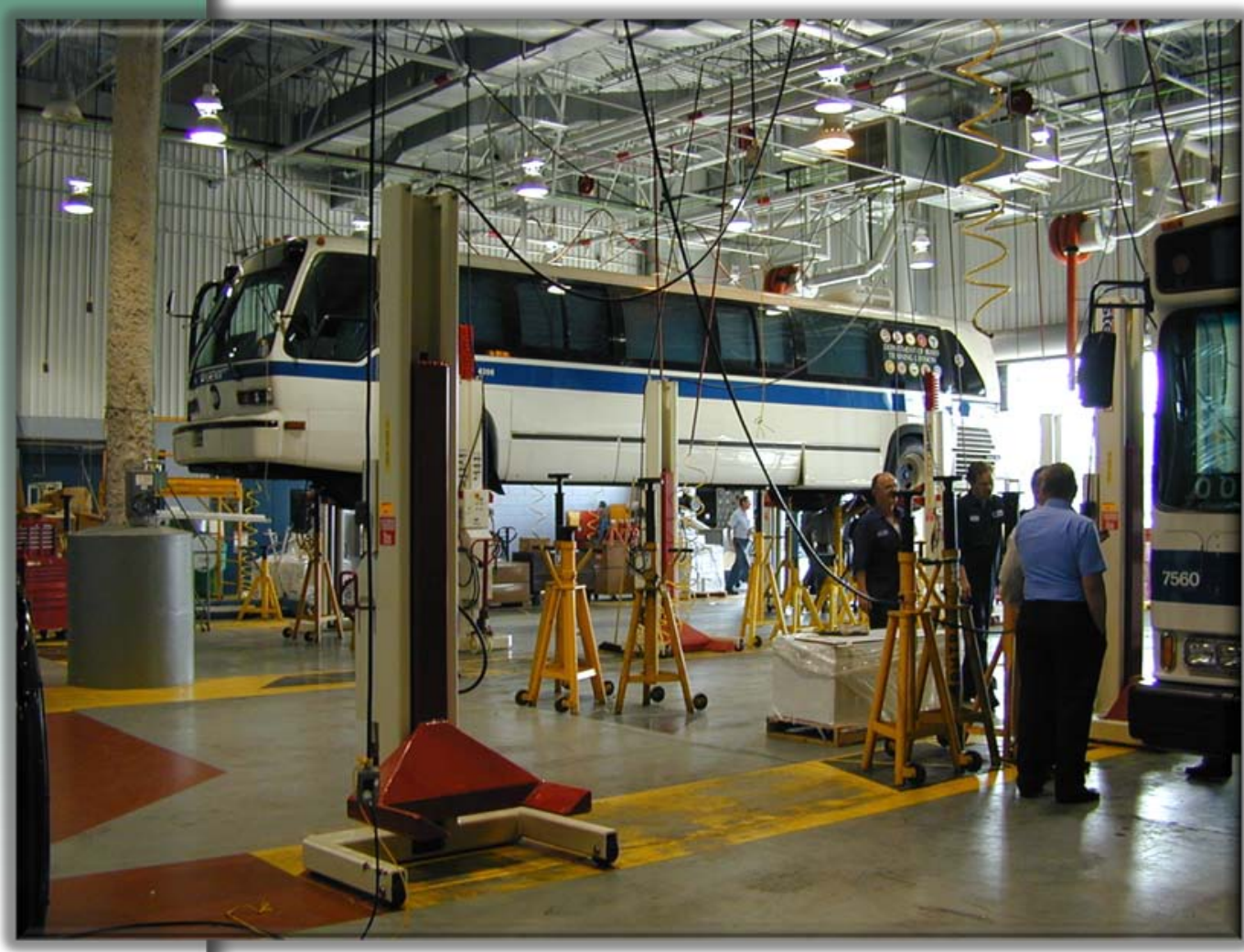

Funded by

Florida Department of Transportation

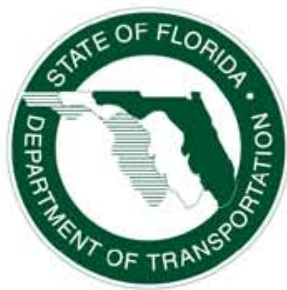

June, 2011

Final Report 


\section{Disclaimer}

The opinions, findings, and conclusions expressed in this publication are those of the authors who are responsible for the facts and accuracy of the data presented herein. The contents do not necessarily reflect the views and policies of the Florida Department of Transportation or the Research and Innovative Technology Administration. This report does not constitute a standard, specification, or regulation. 


\section{Florida Bus Maintenance Staffing Practices}

\section{Project \#BDK85 - Work Order \#977-19}

\section{FINAL REPORT}

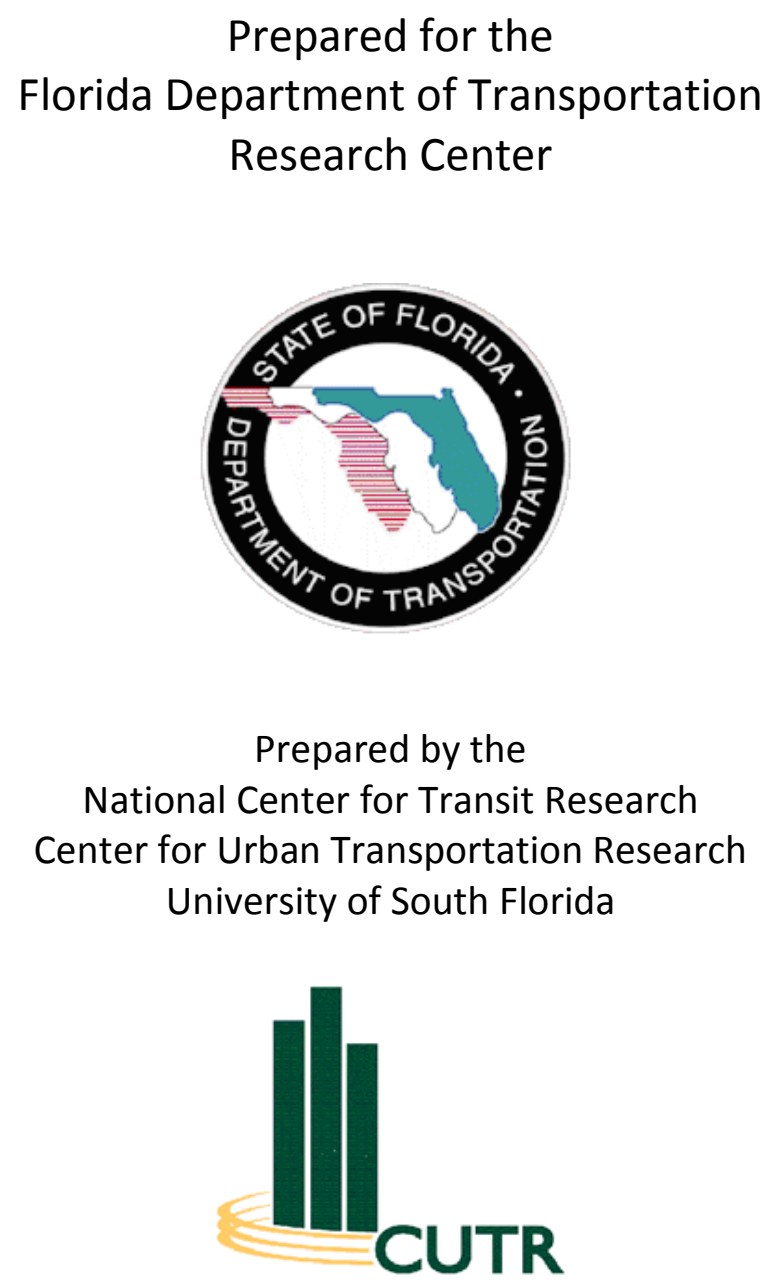

June 2011 


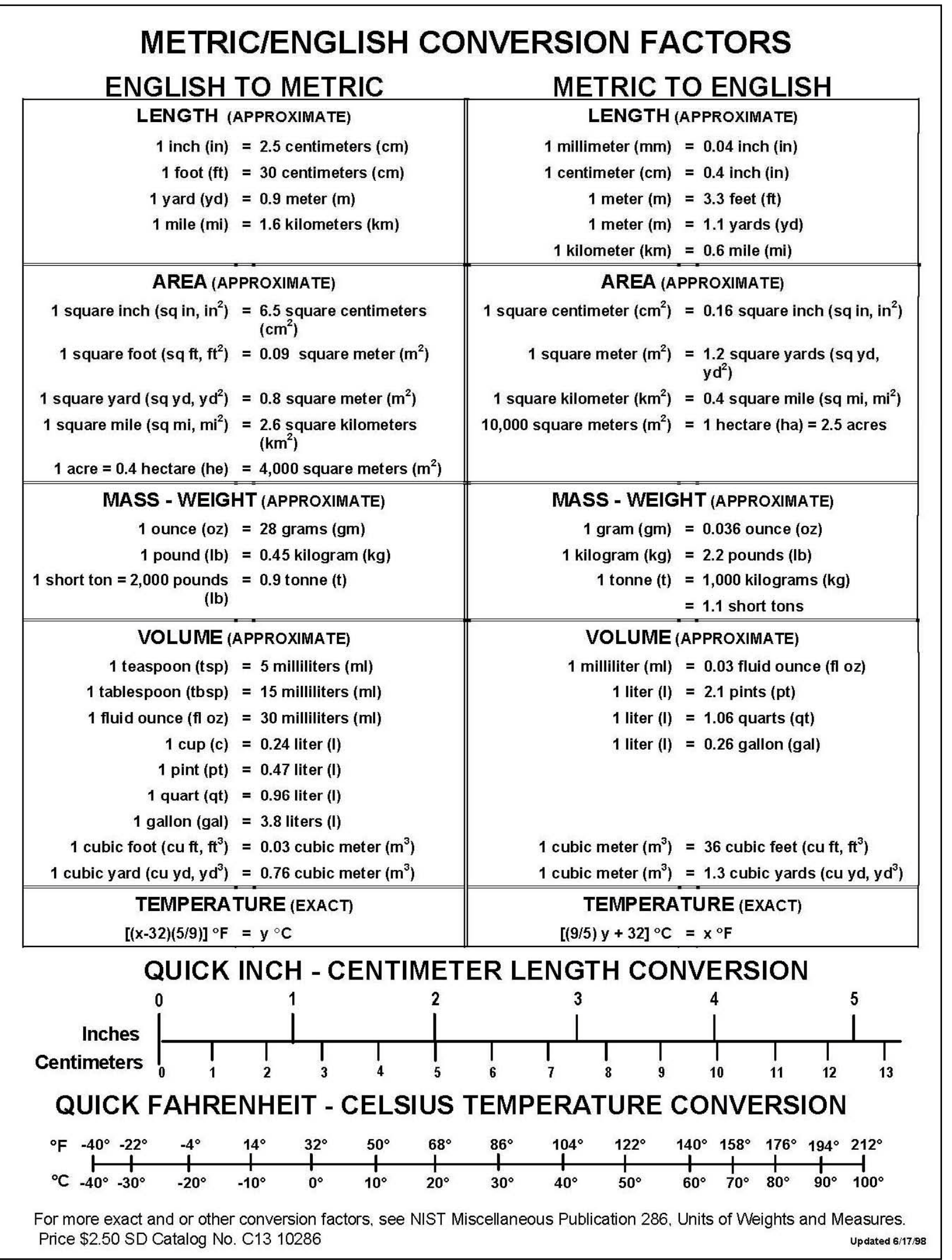




\begin{tabular}{|c|c|c|c|c|}
\hline 1. Report No. & \multicolumn{2}{|c|}{ 2. Government Accession No. } & \multicolumn{2}{|l|}{ 3. Recipient's Catalog No. } \\
\hline \multirow{2}{*}{\multicolumn{3}{|c|}{$\begin{array}{l}\text { 4. Title and Subtitle } \\
\text { Florida Bus Maintenance Staffing Practices }\end{array}$}} & \multicolumn{2}{|l|}{$\begin{array}{l}\text { 5. Report Date } \\
\text { June } 2011\end{array}$} \\
\hline & & & \multicolumn{2}{|c|}{ 6. Performing Organization Code } \\
\hline \multicolumn{3}{|c|}{$\begin{array}{l}\text { 7. Author(s) } \\
\text { Jay Goodwill and Deborah Sapper }\end{array}$} & \multicolumn{2}{|c|}{$\begin{array}{l}\text { 8. Performing Organization Report No. } \\
\text { 2117-77924-00 }\end{array}$} \\
\hline \multicolumn{3}{|c|}{$\begin{array}{l}\text { 9. Performing Organization Name and Address } \\
\text { National Center For Transit Research (NCTR) } \\
\text { Center for Urban Transportation Research } \\
\text { University of South Florida - CUT100 } \\
4202 \text { East Fowler Avenue, Tampa, FL } 33620\end{array}$} & \multicolumn{2}{|c|}{$\begin{array}{l}\text { 11. Contract or Grant No. } \\
\text { BDK85 Task \#977-19 }\end{array}$} \\
\hline \multicolumn{3}{|c|}{$\begin{array}{l}\text { 12. Sponsoring Agency Name and Address } \\
\text { Office of Research and Special Programs (RSPA) } \\
\text { U.S. Department of Transportation, Washington, D.C. } 20590 \\
\text { Florida Department of Transportation } \\
605 \text { Suwannee Street, MS 26, Tallahassee, FL } 32399\end{array}$} & \multicolumn{2}{|c|}{ 14. Sponsoring Agency Code } \\
\hline \multicolumn{5}{|l|}{ 15. Supplementary Notes } \\
\hline \multicolumn{5}{|c|}{$\begin{array}{l}\text { 16. Abstract } \\
\text { This research report focuses on the staffing practices of the bus maintenance departments of } \\
\text { Florida transit agencies. The availability of an adequate transit bus fleet is a key element for a transit } \\
\text { agency's ability to provide high quality, reliable, and safe bus transit service. Critical resources } \\
\text { needed to keep a transit bus fleet available for revenue service include a functional maintenance } \\
\text { department structure, proper staffing plans, and an adequate level of maintenance staffs. } \\
\text { The objective of this project was to help Florida's transit agencies identify the optimal organizational } \\
\text { structures and staffing plans and adequate staffing levels for their bus fleet maintenance programs } \\
\text { and to identify associated critical factors. Florida transit agency bus maintenance units' } \\
\text { organizational structures and staffing practices are detailed. }\end{array}$} \\
\hline \multicolumn{2}{|c|}{$\begin{array}{l}\text { 17. Key Word } \\
\text { Public transportation, bus maintenance, staffing } \\
\text { practices }\end{array}$} & \multicolumn{3}{|c|}{$\begin{array}{l}\text { 18. Distribution Statement } \\
\text { Available to the public through the National } \\
\text { Technical Information Service (NTIS), } 5285 \text { Port } \\
\text { Royal Road, Springfield, VA 22161, (703) 487- } \\
\text { 4650, http://www.ntis.gov/ , and through the } \\
\text { NCTR web site at http://www.cutr.usf.edu/ }\end{array}$} \\
\hline $\begin{array}{l}\text { 19. Security Classif. (of this report) } \\
\text { Unclassified }\end{array}$ & $\begin{array}{l}\text { 20. Security Classif. } \\
\text { Unclassified }\end{array}$ & f this page) & $\begin{array}{r}\text { 21. No. of Pages } \\
39\end{array}$ & $\begin{array}{l}\text { 22. Price } \\
\text { No Cost }\end{array}$ \\
\hline
\end{tabular}




\section{EXECUTIVE SUMMARY}

This project focused on the staffing practices of Florida's transit agencies' bus maintenance departments. The availability of an adequate and well maintained transit bus fleet is a key element for a transit agency's ability to provide high quality, reliable, and safe bus transit service. Critical elements necessary to keep a transit bus fleet operational for revenue service include establishing a functional maintenance department structure, defining proper staffing plans, and ensuring adequate staffing levels.

The objectives of this project were to assist Florida's transit agencies with the identification of the optimal organizational structures, staffing plans, and adequate staffing levels for their bus fleet maintenance programs and those critical elements that may help define those factors. This "Florida Bus Maintenance Staffing Practices - Final Report" outlines those critical inputs that transit agencies should consider when either staffing a new program or evaluating and re-aligning an existing program.

This report recognizes that there are a number of factors in transit operations that make it difficult to develop simple rules of thumb that an agency might use in developing the organizational structure and staffing levels for their maintenance departments. Further, there is considerable risk in an agency implementing another agency's practice without fully understanding the critical inputs under which it evolved. With fleet maintenance accounting for approximately 20 percent of a transit agency's operating budget, combined with the capital investment for the acquisition of the fleet, it is critical that the business process of organizing and staffing an agency's bus maintenance department be tailored to that agency.

While there is no single, up-to-date authoritative source on how to go about managing this aspect of transit operation, there are some general rules of thumb or benchmarking activities that can be used and are discussed within this report. Along with considering various rules of thumb and benchmarking methods, transit maintenance managers can benefit from becoming familiar with the approaches of their peer agencies. Some of these approaches are discussed in this document.

The first phase of the research project was to conduct a literature review to identify any methodologies and findings from previous studies that could serve as a starting point for the research. While there were few research documents or resources uncovered, this activity confirms that there are gaps and deficiencies in the existing body of knowledge in the area of bus maintenance staffing practices. A summary of the literature review is provided in Chapter Two of this report. 
Due to the limited documented data and reports on bus maintenance staffing, it was determined that direct communication with transit agencies would be necessary to understand and articulate bus maintenance staffing practices. Over 100 transit maintenance managers from across the country were contacted through Transportation Research Board's (TRB) Transit Fleet Maintenance Committee's, Bus Fleet Managers' listserv hosted through the National Center for Transit Research (www.nctr.usf.edu) at the Center for Urban Transportation Research at the University of South Florida. The listserv members were asked to identify and share any staffing decision making tools that they use or that they were aware of.

In summary, the responses from maintenance managers from across the country suggest that determining the number of maintenance employees is a task that should rest within an individual agency. Respondents did recognize that general rules of thumb are used, but noted that agencies must look at factors specific to their system to establish acceptable benchmarks and ratio goals. Those factors identified by maintenance managers that should be considered include, but are not limited to type of operation; vehicle miles; portion of maintenance activities that are contracted rather than performed inhouse; amount of down-time or non-work hours of mechanics during a 40-hour work week; weather/seasonal characteristics; average age of the vehicle fleet; preventive maintenance intervals; and the terms included in labor agreements.

Additionally, the researchers made a concerted effort to obtain and review the maintenance plans for Florida's Federal Transit Administration (FTA) Section 5307 funded systems to help identify maintenance philosophies and approaches, agency organization structures, staffing patterns, and other relevant information that would assist in this research effort. On June 2, 2010, an e-mail letter was sent to all fixed route transit systems requesting the following items:

- A copy of the maintenance department's organizational chart;

- The position/job descriptions for the agency maintenance staff; and

- A copy of the agency's maintenance plan.

Thirteen transit agencies provided position descriptions for their maintenance department employees. These position descriptions are contained in Technical Memorandum \#2 and are grouped by transit agency. These position descriptions may be useful to transit maintenance departments who are reviewing their current job descriptions or adding positions. A few agencies also provided copies of their maintenance plans and organizational charts.

Based upon the findings of the literature review, input received through the Bus Fleet Managers' listserv, the review of the system maintenance plans, and other guidance received, a survey instrument was developed to collect additional information on transit agencies' overall organizational structures; 
the bus maintenance organizational structures; staffing patterns (i.e., position types, number of positions, position descriptions, etc.); bus fleet information; and related factors that help define bus maintenance staffing thresholds and resultant hiring practices.

The survey instrument was administered as a web-based survey using SurveyMonkey ${ }^{\mathrm{TM}}$ and consisted of questions grouped into the following categories:

- General Information

- Fleet Size and Composition

- Maintenance Operations/Facilities

- Staffing

A comprehensive discussion of the survey responses is provided in Chapter Three of this Final Report. To summarize, a few observations were made based upon review of the survey responses. There were 13 systems that could be considered "responsive" to the request for information initiated in June 2010 or the survey questions (i.e., answered the majority of the questions and provided some narrative in their reply). Out of these 13 systems, 6 indicated that they are understaffed. The majority of these agencies noted budgetary limitations or hiring freezes as the primary reasons for this. Eight agencies reported the necessity of overtime: Palm Tran which reported 12 percent overtime, followed by StarMetro and Pinellas Suncoast Transit Authority (PSTA) at 10 percent; RTS at 9.1 percent; Pasco County at 5 percent; ECAT at 3 percent; and MDT at 2 percent.

There was great variability among transit maintenance departments in the maintenance activities conducted in-house and those maintenance activities that are contracted. In general, larger transit agencies (i.e., number of vehicles and vehicle miles) tend to perform most maintenance activities inhouse, including major transmission and engine rebuilds, and collision repair and other body work. Smaller agencies tend to outsource work, primarily rebuilds and major collision body work. All systems that responded to the survey perform their own routine preventive maintenance. These are factors that could make establishing standard man-hour ratios difficult. The variation in the type of repairs made by each agency has implications both for the number of maintenance positions required and the amount of budget that must be allocated to the maintenance department.

Chapter Four provides a summary of information compiled during the research project and the results of the project. It also addresses the factors in transit operations that make it challenging to develop simple rules of thumb or a "magic formula" that an agency might use in developing their own organizational structure and staffing levels. It notes the importance of using a business process tailored specifically to each agency when organizing and staffing an agency's bus maintenance department. The responses from maintenance managers from across the country reflect a consistent theme of a tailored, agency- 
specific process with local variables. General rules of thumb that can be used and can be beneficial to maintenance managers are included. However, it is suggested that transit agencies consider factors specific to their system to establish acceptable benchmarks and ratio goals.

In summary, the "Florida Bus Maintenance Staff Practices" project:

- Uncovered and documented rules of thumb that have been and are currently used by maintenance managers across the country;

- Identified some approaches used by transit systems to evaluate their staffing levels and conduct analysis to determine the correct staffing ratios for their department; and

- Calculated benchmark ratios for 10 Florida transit systems, based on 2009-2010 National Transit Database reports. 


\section{CONTENTS}

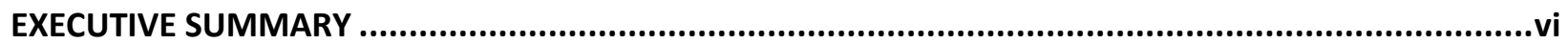

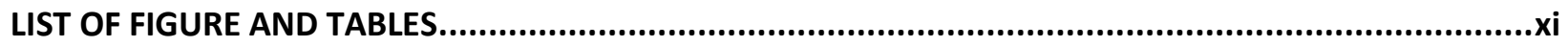

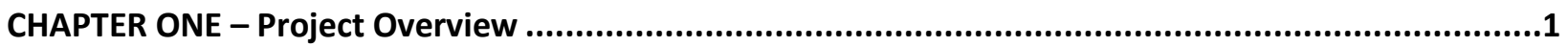

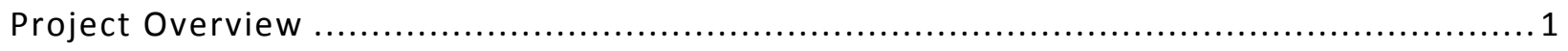

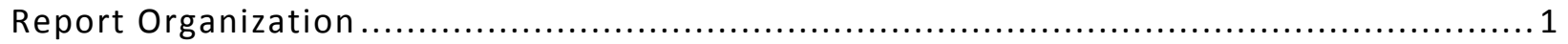

CHAPTER TWO - Literature Review and Background Research ................................................... 4

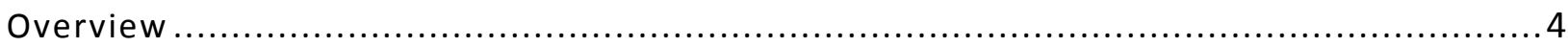

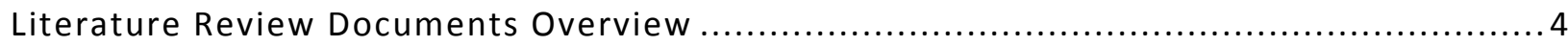

Outreach to the Nation's Transit Bus Fleet Managers ..................................... 12

Maintenance Philosophies and Approaches of Florida FTA Section 5307 Systems .......... 15

CHAPTER THREE - Survey of Florida Transit Agencies Regarding Current Bus Maintenance Staffing

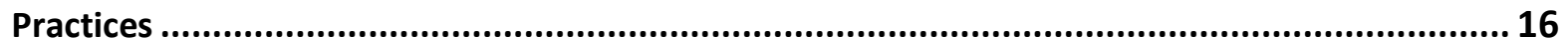

Survey of Florida's FTA Section 5307 Systems ................................................ 16

Compilaton of Agency Data Collected................................................... 16

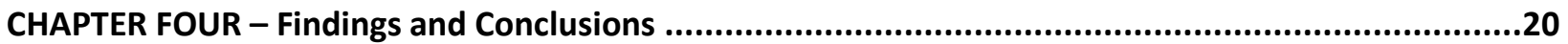

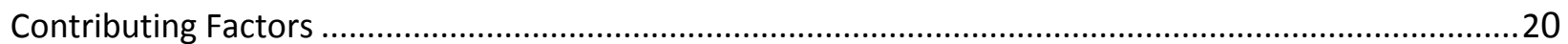

Approaches to Determine Bus Maintenance Mechanic Staffing Needs.......................2 27

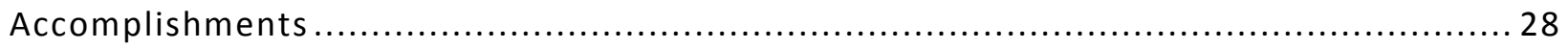

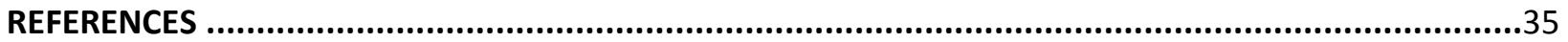




\section{LIST OF FIGURE AND TABLES}

\section{FIGURE}

FIGURE 1 - Graphic Solution to Air, Steering, and Suspension Man-Hours

\section{TABLES}

TABLE 1 - Ratio of Mechanics per Revenue Miles and Revenue Hours .......................................10

TABLE 2 - Florida Transit Agencies Responding to Request and Survey ......................................... 17

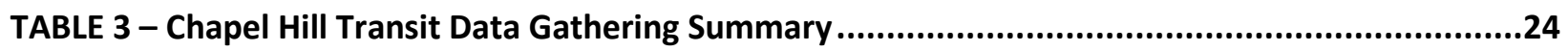

TABLE 4 - Florida Transit System Mechanic and Staffing Ratios ..................................................26 


\section{Chapter One \\ Project Overview}

\section{Project Objective}

This project focused on the staffing practices of Florida's transit agencies' bus maintenance departments. The availability of an adequate and well maintained transit bus fleet is a key element for a transit agency's ability to provide high quality, reliable, and safe bus transit service. Critical elements necessary to keep a transit bus fleet operational for revenue service include establishing a functional maintenance department structure, defining proper staffing plans, and ensuring adequate staffing levels.

This report recognizes that there are a number of factors in transit operations that make it difficult to develop simple rules of thumb that an agency might use in developing the organizational structure and staffing levels for their maintenance departments. Further, there is considerable risk in an agency implementing another agency's practice without fully understanding the critical inputs under which it evolved. With fleet maintenance accounting for approximately 20 percent of a transit agency's operating budget, combined with the capital investment for the acquisition of the fleet, it is critical that the business process of organizing and staffing an agency's bus maintenance department be tailored to that agency.

While there is no single, up-to-date authoritative source on how to go about managing this aspect of transit operations, there are some general rules of thumb or benchmarking activities that can be used and are discussed within this report. Along with considering various rules of thumb and benchmarking methods, transit maintenance managers can benefit from becoming familiar with the approaches of their peer agencies. Some of these approaches are discussed in this document.

The objective of this project was to assist Florida's transit agencies through the identification of the optimal organizational structures, staffing plans, and adequate staffing levels for their bus fleet maintenance programs and those critical elements that may help define those factors. This "Florida Bus Maintenance Staffing Practices - Final Report" outlines those critical inputs that transit agencies should consider when either staffing a new program or evaluating and re-aligning an existing program.

\section{Report Organization}

Two technical memorandums were developed that summarize the findings of the project tasks, including the literature review; input received from maintenance managers through the Transportation Research Board (TRB), Transit Fleet Maintenance Committee's, Bus Fleet Manager's listserv; the 
collection of relevant materials from Florida transit agencies, including position descriptions; and the survey of Florida's bus maintenance departments. This material is summarized in this Final Report, but the authors elected not to repeat the bulk of the detailed system information and position descriptions in this document. The reader should refer to the two technical memorandums to access this valuable resource information.

\section{Chapter Two - Literature Review and Background Research}

Chapter Two provides the summary of the literature review and the background research. This activity was conducted during the first phase of the research project to identify any methodologies and findings from previous studies that could serve as a starting point for the research. While there were few research documents or resources uncovered, this activity did confirm that there are gaps and deficiencies in the existing body of knowledge in the area of bus maintenance staffing practices.

Due to the limited documented data and reports on bus maintenance staffing, it was determined that direct communication with transit agencies would be necessary to understand and articulate bus maintenance staffing practices. Over 100 transit maintenance managers from across the country were contacted through TRB's Transit Fleet Maintenance Committee's, Bus Fleet Managers' listserv hosted through the National Center for Transit Research (www.nctr.usf.edu) at the Center for Urban Transportation Research at the University of South Florida. The listserv members were asked to identify and share any staffing decision tools that they use or that they are aware of. A summary of the responses received from those members of the Bus Fleet Managers' listserv is also provided in Chapter Two.

Additionally, the researchers made a concerted effort to obtain and review the maintenance plans for Florida's Federal Transit Administration (FTA) Section 5307 funded systems to help identify maintenance philosophies and approaches, agency organization structures, staffing patterns, and other relevant information that might assist in this research effort. Any key elements or lessons learned through this activity are also discussed in this chapter.

Combined, the information gathered from these efforts provided a background upon which to develop the agency survey instrument and key questions for the more in depth follow up interviews. A summary of the agency survey results are contained in Chapter Three.

\section{Chapter Three - Survey of Florida Transit Agencies Regarding Current Bus Maintenance Staffing Practices.}

Based upon the findings of the literature review, input received through the Bus Fleet Managers' listserv, the review of the system maintenance plans, and other guidance received, a survey instrument was developed to collect additional and missing information on transit agencies' overall organizational 
structure; the bus maintenance organizational structure; staffing patterns (i.e., position types, number of positions, position descriptions, etc.); bus fleet information; and related factors that help define bus maintenance staffing thresholds and resultant hiring practices.

The survey instrument was administered as a web-based survey using SurveyMonkey ${ }^{\mathrm{TM}}$ and consisted of questions grouped into the following categories:

- General Information

- Fleet Size and Composition

- Maintenance Operations/Facilities

- Staffing

A comprehensive discussion of the survey responses is provided in Chapter Three of this Final Report.

\section{Chapter Four - Findings and Conclusions}

Chapter Four provides a summary of information compiled during the research project and the results of the project. It also addresses the factors in transit operations that make it challenging to develop simple rules of thumb or a "magic formula" that an agency might use in developing their own organizational structure and staffing levels. It notes the importance of using a business process tailored specifically to each agency when organizing and staffing an agency's bus maintenance department. The responses from maintenance managers from across the country reflect a consistent theme of a tailored, agencyspecific process with local variables. General rules of thumb that can be used and can be beneficial to maintenance managers are included. However, it is suggested that transit agencies consider factors specific to their system to establish acceptable benchmarks and ratio goals. 


\section{Chapter Two \\ Literature Review and Background Research}

\section{Overview}

The first phase of the research project was to conduct a literature review to identify any methodologies and findings from previous studies that could serve as a starting point for the research. As expected, there were few research documents available to serve as resources. What this did confirm is that there are gaps and deficiencies in the existing body of knowledge in the area of bus maintenance staffing practices.

Background research was supplemented with information obtained from maintenance managers across the country through the TRB Transit Maintenance listserv and the review of maintenance plans from Florida's fixed route providers. A summary of the findings of these activities is also provided within this chapter.

\section{Literature Review Documents Overview}

While the availability of reports or documented data summaries on bus maintenance staffing practices is limited, there were a few useful resources identified. A summary of these documents is provided in this section.

\section{"Mechanic Manpower Analysis for Miami-Dade Transit," USF Center for Urban Transportation Research, June 2003}

This report was produced by the Center for Urban Transportation Research at the University of South Florida for the Miami-Dade Transit (MDT) system in 2003 in anticipation of their planned service expansion. A methodology for predicting maintenance staffing requirements was developed by MDT maintenance managers. MDT requested CUTR's assistance to "ascertain the soundness of the methodology as a predictor of maintenance staff needs."

- The analysis utilized FY 2001 system and maintenance data and histories. Data used for the analysis included:

o $26,481,222$ annual vehicle miles

o 162 full-time mechanics

o 293,559 annual work hours, including overtime

- The methodology identified the number of full-time mechanics required to provide a defined volume of vehicle miles. 
- The methodology acknowledged and forecasted the annual availability of the typical full-time mechanic, using these assumptions:

o A mechanic would be available to work 261 days per year (i.e., 365 days less 2 days off per week)

o Due to holidays, annual leave and sick leave, 39 of those days were considered "unavailable days"

0 This left a balance of 222 days of availability

o In a typical workday of an 8-hour shift, approximately one hour per day is consumed with breaks (including lunch) and clean-up time. This resulted in daily availability for maintenance function of 7 hours per day.

o Therefore, typical availability of a mechanic was estimated to be 1,554 hours per year (i.e., 261 days $x 7$ hours per day).

Utilizing Miami-Dade Transit FY 2001 system data, the following formula was developed to determine the number of full-time mechanics required for the projected mileage volumes:

\begin{tabular}{|l|l|}
\hline $\begin{array}{l}\text { Number of Full-time } \\
\text { Mechanics Required }\end{array}=\quad \begin{array}{l}\text { Total Vehicle Miles/ } \\
155,400 \text { Miles per Mechanic }\end{array}$ \\
\hline
\end{tabular}

A separate analysis was performed for body mechanics. The analysis followed the same procedure used to estimate the number of full-time mechanics needed. The formula to determine the number of fulltime body mechanics required for total vehicle miles was:

\begin{tabular}{|l|}
\hline $\begin{array}{l}\text { Number of Full-time } \\
\text { Body Mechanics } \\
\text { Required }\end{array}$ \\
\hline
\end{tabular}

The evaluation determined that the methodology developed to determine manpower requirements for both mechanics and body mechanics was sound. The ability of MDT's maintenance reporting system to capture approximately 92 percent of work hours lent credibility to the analysis. 
"Public Transit Bus Maintenance Manpower Planning, Report 10, National Cooperative Transit Research and Development Program," Transportation Research Board, December 1984

This report examined the factors contributing to bus maintenance manpower needs. The report utilized the maintenance histories of 15 transit agencies from across the United States, with data from 1983 and earlier. The analytical report resulted in a maintenance planning model that quantified the impact of local characteristics such as vehicle-miles, peak vehicles, climate, fleet-mix, accident frequency, and agency overtime practices.

The report acknowledged the challenges of manpower planning for bus maintenance, specifically when considering the day-to-day variation of work tasks and the difficulty of measuring an individual mechanic's productivity. Additionally, while some maintenance functions can be scheduled (e.g., preventive maintenance, cleaning and inspections) many maintenance work functions must be available upon demand (e.g., road calls and repairs). The volume and frequency of those "on demand" repairs cannot be predicted. It was also noted that the availability of reliable maintenance data was problematic. (The ability of maintenance managers to track their performance has improved since this report was written with the availability of improved maintenance software systems.)

The report developed a series of nomographs - charts containing scales for the variables in the mathematical equations developed, that permits the use of a straight edge to identify agency operating parameters and the corresponding man-hour requirements for the work function. The following is an example of such a graphical solution to determine agency maintenance manpower requirements for air, steering and suspension maintenance. 


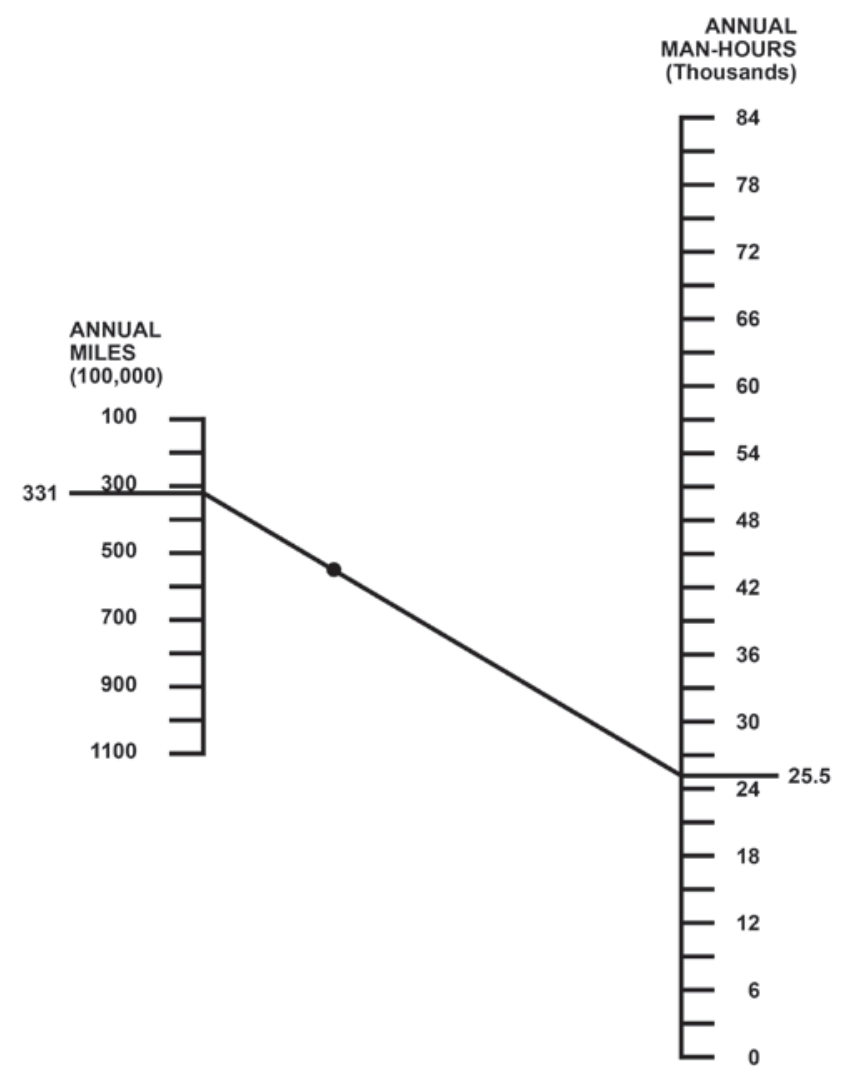

FIGURE 1

Graphic Solution to Air, Steering, and Suspension Man-Hours

It was not possible to determine if this methodology was accepted and applied in the transit industry. Additionally, no updates of this report were identified.

\section{"Evaluation of Maintenance Manpower Utilization" Transportation Research Board, Transportation} Research Record Issue No. 1019, pgs 49-62, 1985

The evaluation was conducted based upon detailed maintenance data collected from 15 public transit bus agencies that included a cross section of these agencies providing variation in system size and location. Consideration was made to address the differences of these agencies in terms of fleet size and composition, topography and climate of the operating environment, and fleet utilization statistics. Maintenance manpower requirements were developed on the basis of detailed work activities by vehicle "subfleet" and functional area. The researchers conducted a series of statistical analyses to compare the range of maintenance requirements and to account for variances in the amount of time 
that is required for each type of repair activity and the frequency of repair by vehicle system and subfleet. The analysis provided a basis for a manpower model that would allow maintenance managers to better plan for their manpower requirements on the basis of the specific site criteria of the agency.

While unknown if this resource has been widely used in the bus transit industry, it does provide a comprehensive review of elements that must be considered in setting man-hour goals or ratios for bus maintenance staffing.

\section{"Evaluation of Bus Maintenance Operations" Transportation Research Board, Transportation Research Record Issue No. 1019, pp. 77-84, 1985}

This report examined the environmental and policy factors that may influence and constrain the operation of a maintenance department. The study defined the maintenance function as a set of eight component activities, which are work assignment, maintenance scheduling, workforce development, labor allocation, inventory management, equipment management, information systems, and monitoring and evaluation. The external factors and maintenance activities were reviewed and analyzed to develop a profile of a bus system's maintenance department. This descriptive framework was used to demonstrate that different levels of activities are appropriate for different sets of external factors. Finally, applications of the framework at the transit-agency level are discussed.

While unknown if this resource has been widely used in the bus transit industry, it does identify and discuss those external factors that impact resource allocation and staffing levels for bus transit maintenance departments.

"Fleet Maintenance Operations Guide," NAFA Fleet Maintenance Association, Chapter 7 Maintenance Staffing, pp. 409-424, June 2009.

This resource document was produced by the NAFA Fleet Maintenance Association and provides guidance in a variety of aspects related to fleet maintenance. While not bus or transit specific, the concepts and direction provided are applicable to bus fleet maintenance managers. Chapter 7 addresses Maintenance Staffing.

The recommended approach to determine maintenance staff needs was based on the concept of "vehicle equivalency analysis." This approach provided a methodology to break down a diverse fleet (i.e., bus fleet mixes, service vehicles and staff vehicles) into common categories of required maintenance man-hours for each type. Utilizing fleet maintenance histories, maintenance requirements by vehicle type category can be determined and then applied to the number and mix of vehicles. 
This methodology acknowledged the "loss time" of the average maintenance technician based on days off due to breaks, holidays, annual leave, sick leave, and training. The document states that on average, a technician is available for actual fleet maintenance work 80 percent of a 40 -hour workweek, or 1,415 hours per year.

The document also emphasizes the desirability of employing adequate support employees with lesser skills to perform the more menial and routine maintenance tasks like cleaning bays, acquiring parts, pulling buses into the shop and test drives. It further recommends that maintenance managers develop written personnel job descriptions and create job classifications that support the agency's needs.

\section{“Characteristics of Urban Transportation Systems, $7^{\text {th }}$ Edition" Federal Transit Administration, September 1992}

The objective of this report was to provide a single source of planning data based on those characteristics determined to be most important in an urban transportation system. It was created to assist agencies in making educated decisions on transportation investments and policies. The report is organized by mode, with transit divided between "Rail Transit" and "Bus Transit." A number of performance characteristics were examined and reported for "Bus Transit" including:

- Speeds

- Operating costs

- Labor requirements

- Energy consumption

- Capital and rehabilitative costs

- Performance characteristics

- Capacities

- Accident rates

In reporting overall bus labor statistics, the researchers allowed for variation in system size (number of buses operated) when calculating the number of employees (full time equivalents) per revenue miles, revenue hours, passenger miles, and per peak vehicle usage. Within each system size category, average, low, and high ratios were included.

Following the examination of labor ratios for all categories of employee, the report disaggregated the results, providing the ratio of vehicle mechanic per 1,000 revenue vehicle miles. The results are provided in the Table 1 below. (The writers of this report converted the ratio to be reflected as vehicle mechanics per 100,000 revenue miles.) Also included are the ratios for vehicle mechanics per 1,000 revenue hours. 
TABLE 1

Ratio of Mechanics per Revenue Miles and Revenue Hours

\begin{tabular}{|c|c|c|}
\hline Size of System & $\begin{array}{c}\text { Vehicle Mechanics*/100,000 } \\
\text { Revenue Miles }\end{array}$ & $\begin{array}{c}\text { Vehicle Mechanics/1,000 } \\
\text { Revenue Hours }\end{array}$ \\
\hline \multicolumn{3}{|l|}{250 or more buses } \\
\hline Average & 1.2 & 0.15 \\
\hline Low & 0.7 & 0.10 \\
\hline High & 2.2 & 0.23 \\
\hline \multicolumn{3}{|l|}{$100-249$ buses } \\
\hline Average & 0.9 & 0.12 \\
\hline Low & 0.3 & 0.05 \\
\hline High & 2.7 & 0.29 \\
\hline \multicolumn{3}{|l|}{$50-99$ buses } \\
\hline Average & 0.8 & 0.12 \\
\hline Low & 0.2 & 0.04 \\
\hline High & 1.9 & 0.32 \\
\hline \multicolumn{3}{|l|}{$25-49$ buses } \\
\hline Average & 0.7 & 0.10 \\
\hline Low & 0.2 & 0.03 \\
\hline High & 1.5 & 0.19 \\
\hline \multicolumn{3}{|l|}{ Fewer than 25 buses } \\
\hline Average & 0.7 & 0.10 \\
\hline Low & 0.0 & 0.02 \\
\hline High & 2.9 & 0.32 \\
\hline Average & 0.8 & 0.11 \\
\hline
\end{tabular}

*Mechanics were defined as "revenue vehicle inspection and maintenance" employees. Outliers - those that would have skewed the results - were not included in the calculations.

Source: "Characteristics of Urban Transportation Systems," Federal Transit Administration, September 1992 (format modifications made by CUTR, 2011).

The recognition that system size makes a difference in the number of mechanics needed to support a transit system is viewed to be an acceptable consideration when establishing a method of examining labor statistics. Other factors, for example the amount of maintenance activities that are contracted out and average age of the bus fleet, would be valuable components in making recommendations regarding a ratio of bus mechanics per 1,000 (or 100,000 ) revenue miles or 1,000 revenue hours.

The use of revenue vehicle miles rather than vehicle miles could be problematic in areas with excessive deadhead miles or other characteristics that impact the difference between total vehicle miles and revenue vehicle miles. A similar point could be made with the use of revenue hours rather than total hours. Because this report was completed in 1992, it would not necessarily reflect the man-hour needs 
of systems today. Of particular note are the significant improvements made to diagnostic tools, maintenance management systems, and changes to transit vehicles that now include the incorporation of advanced electrical systems, and components, that would impact overall man-hour requirements.

However, this report does provide a tool for comparison purposes, allowing transit maintenance managers to make general observations about their system compared to those of similar system size.

\section{"Town of Chapel Hill - Transit Maintenance Staff Analysis," conducted by Parsons Brinkerhoff, Inc. 2003}

In 2003, Chapel Hill Transit (CHT) identified a need to conduct an evaluation of their Transit Maintenance Division to determine if the current staffing levels were adequate to meet vehicle service demand and maintenance requirements. The report provided a summary of current staffing levels, required staff levels for the existing fleet, and proposed staffing levels for any fleet expansion.

In 2003, CHT operated both fixed route and demand response services within a 25 square mile service area. The system provided over 140,000 annual hours of service, 2,300,000 annual vehicle miles and carried approximately 5 million passengers per year. The CHT fleet consisted of 112 vehicles, including 83 fixed route vehicles, 11 paratransit vehicles, 8 non-revenue support vehicles, 6 "operator relief vehicles," and 4 "parking" vehicles.

At the time this report was written, $\mathrm{CHT}$ had 21 staff positions as follows:

- Maintenance Superintendent (1 position)

- Maintenance Supervisor (1 position)

- Mechanics I, II, and III (8 positions)

- Bus Service Technician (1 position)

- Mechanic Helper (2 positions)

- Service Attendant (5 positions)

- Parts Manager (1 position)

- Administrative Clerk (1 position)

There were no positions budgeted for completing facility and "bus zone" maintenance. However, the Transit Maintenance Division was responsible for these activities, as well as repairs and cleaning of bus benches and shelters.

The consultant completed a data collection phase and staff assessment. This resulted in a finding that "the transit maintenance division is significantly understaffed." The effects of understaffing included issues related to bus cleanliness, low morale due to the staff levels and inadequate skill development 
training, ineffective system diagnosis practices, and vehicles remaining out of service for extended periods of time.

The consultants recommended the creation of a position for a Maintenance Manager/Assistant Director; two additional Maintenance Supervisor positions; up to two additional Part Clerks; a Bus Zone Maintenance Worker; five additional Mechanic positions; two additional Bus Service Technicians; one additional Service Attendant; a new Vehicle Detail Cleaner position with three staff assigned. The implementation of these changes would result in an increase to 34 positions.

PB, Inc. used the formulas provided in TRB's "Public Transit Bus Maintenance Manpower Planning" Report 10 (referenced above). The results of their analysis identified the following standards for CHT's maintenance positions.

Vehicles Per Mechanic Staff

7.05

Vehicles Per Service and Cleaning Staff

Vehicles Per Vehicle Detail Staff
17.92

37

The City of Chapel Hill did respond to the survey discussed in the following section. The ratio of vehicles per mechanic staff has now been increased to 7.62 buses per mechanic staff. This ratio was developed through a benchmarking approach used by the $\mathrm{CHT}$ Superintendent of Maintenance and includes ratios for $\mathrm{CHT}$, and several systems in North Carolina and across the country.

\section{Outreach to the Nation's Transit Bus Fleet Managers}

Due to the limited research available on bus maintenance staffing, the researchers contacted over 100 transit maintenance managers from throughout the country utilizing the Transportation Research Board Transit, Fleet Maintenance Committee's Bus Fleet Manager's listserv, hosted by the National Center for Transit Research (www.nctr.usf.edu) located at the Center for Urban Transportation Research at the University of South Florida. The listserv members were asked to identify and share any staffing decision tools that they use or that they are aware of. One listserv inquiry with its associated responses are provided below. A summary of the inquiries and responses are discussed in Technical Memorandum \#1, with the inquiries and responses also included in Appendices $A$ and $B$ of that document.

In one member's inquiry, the listserv members were asked to provide feedback on their bus-tomechanic ratio. This section includes the original inquiry and the responses received. 


\section{Question Posed by Carl Rokos, Superintendent of Maintenance, Chapel Hill Transit}

Once again I would like to ask everyone to give some feedback. What is your bus to mechanic ratio?

Mine is 7.62 bus or 10.31 vehicles per mechanic. I have attached a spreadsheet; if possible can you add your numbers and send back to me?

NOTE: The spreadsheet is provided in Chapter 4.

\section{Response \#1: Dennis M. Gristofaro, Chicago Transit Authority}

However, without seeing your worksheet, the question or answer that you are seeking is a variable for each of us. Your type of operation, miles traveled, type of work performed, seasons, weather, age of equipment, type of equipment, PM interval, etc. are all factors that determine what your workforce should be. However, we all wish that there was a magic formula.

Response \#2: Frank Spielberg, Program Manager, VHB, Inc.

One problem is that agencies seem to "get the line out" every day even if the facility is too small or the staff is inadequate (or vice-versa, although this is unusual). Simply basing the findings on observed practice without some further research as the backlogs or deferred maintenance can lead to understating true needs.

One key item to check at the agencies is the PM schedule and the degree to which PMs are performed on time.

Response \#3: Brooks McAllister, Director, Maintenance Division, Georgia Regional Transportation Authority (GRTA)

I've looked in a lot of places for that particular answer. I agree with Mike that it is fleet and mileage dependent for garage techs. Back shop manning is a little easier to figure because you can pretty well forecast the number of work hours required for each skill.

The best rule of thumb I have seen comes out of DOD - they figure one hour of unscheduled maintenance for every ten hours of operation, add the total number of PM hours to that, and divide by 2080. It might be a little fat, but not very much. 
Response \#4: Bill Spies, Director of Maintenance, Pierce Transit

Just a comment on the available hours you used below to compute FTEs. We use an annual total of 1560 direct labor hours per FTE when calculating FTEs needed for staffing purposes. This is an estimate of what the actual available hours are for an average mechanic to be productive on the floor. This does not include absences for sick leave, vacation, meetings, training etc. I know some other fleets use 1600 or 1650 per year as well depending on whether or not they include break time in their work order hours.

Response \#5: Brooks McAllister, Director, Maintenance Division, GRTA

Good point. The 2080 figure apparently includes everything, from what I've been able to find out.

Response \#6: Mike Wehr, Milwaukee County Transit System (MCTS)

Regarding the staff size question, "Characteristics of Urban Transportation Systems", September 1992, prepared for the FTA, on page 51 of the audit report, the reference for staff size is:

" 1 mechanic for 3 to 3.5 peak buses and/or 1 mechanic for every 100,000 to 125,000 miles in City operations with 1 mechanic for every 150,000 to 175,000 miles for Suburban operations"

Response \#7: Mike Hubbell, Vice President, Maintenance, Dallas Area Rapid Transit

With all due respect, to my distinguished colleague, this report was published in 1992 with data collected on a vehicle configuration that is now in excess of 19 years old. This analysis was done long before the inclusion of much of the equipment included on today's vehicles, which adds additional maintenance burdens to the system. Examples of that equipment are security cameras; exhaust emissions/alternate fuels; automatic passenger counters, voice annunciator systems to name just a few.

In addition, each labor contract varies from property to property and has a direct impact on the actual labor hours that is available out of the 2,080 hours of a typical "pay year."

I would first look internally at your own data to determine what your available annual labor hours are given the provisions of your labor agreement and work rules. Then use your maintenance records data to determine what your productivity time is for your most frequently performed tasks (typically your PM program, daily servicing and brake relines). From there, look to where you can make improvements in those tasks to gain efficiency, either through modifications of the work flow or labor negotiations. 
Response \#8: Tony Locicero [tolo@buddinet.com]

Agree completely. This assumes a decent VMS to track time. Most systems that I've looked at, and used, are NOT very accurate. Most systems mentioned here in earlier conversations were not very good in real life service. Procurement of an accurate labor tracking system, with highlevel data resolution, is the first thing I would do. Another is overtime expended vs. regular hours. Amazing how many properties can't seem to find funding for bodies but seem to have the cash to work $20 \%-30 \%$ overtime every week.

In summary, the responses from maintenance managers from across the country suggest that determining the number of maintenance employees is a task that should rest within an individual agency. General rules of thumb are used, but agencies must look at factors specific to their system to establish acceptable benchmarks and ratio goals. Those items that should be considered include, but are not limited to: type of operation; vehicle miles; portion of maintenance activities that are contracted rather than performed in-house; amount of down-time or non-work hours of mechanics during a 40hour work week; weather/seasonal characteristics; average age of the vehicle fleet; preventive maintenance intervals; and the terms included in labor agreements.

\section{Maintenance Philosophies and Approaches of Florida FTA Section 5307 Systems}

The final effort in this task was to gather pertinent information and data from Florida's fixed route transit agencies (i.e., those receiving Federal Transit Administration Section 5307 funding). In June 2010, an email letter was sent to all fixed route transit providers requesting the following items:

- A copy of the maintenance department's organizational chart

- The position/job descriptions for the agency maintenance staff

- A copy of the agency maintenance plan (this will be used to help us identify maintenance philosophies and approaches, agency organization structures, and staffing patterns)

The request made in June 2010 resulted in a number of responses. Thirteen Florida transit agencies provided position descriptions for their bus maintenance departments. These position descriptions are contained in Technical Memorandum \#2 and are grouped by transit agency. Although each agency uses different position titles and position description formats, this set of position descriptions will provide a rich resource for transit agencies that are considering revising their position descriptions or adding new positions to their bus maintenance staffs. 


\section{Chapter Three \\ Survey of Florida Transit Agencies \\ Current Bus Maintenance Staffing Practices}

\section{Survey of Florida's FTA Section 5307 Systems}

Based upon the findings of the literature review, the responses received through TRB's Bus Fleet Managers' listserv, the review of the system maintenance plans, and other guidance received, a survey instrument was developed with the intent to collect additional and missing information on current transit agencies' overall organizational structure. Specific information was requested regarding the bus maintenance organizational structure, staffing patterns (e.g., position types, number of positions, and position descriptions), bus fleet information, and related factors that help drive the bus maintenance staffing needs.

The survey instrument was administered as a web-based survey using SurveyMonkey ${ }^{\mathrm{TM}}$ and consisted of questions grouped into the following categories:

- General Information

- Fleet Size and Composition

- Maintenance Operations/Facilities

- Staffing

This survey was reviewed and approved by the FDOT project manager and distributed to the maintenance managers of all of Florida's FTA Section 5307 funded systems on December 2, 2010. Ten responses were received.

\section{Compilation of Agency Data Collected}

Table 2 identifies those Florida transit agency maintenance departments that responded to the survey. Respondents to the initial information requested from June 2010 are also indicated. The balance of this section provides a recap by agency of the information and detail collected in the survey tasks, as well as the initial inquiry. 
TABLE 2

Florida Transit Agencies Responding to Request and Survey

\begin{tabular}{|c|c|c|}
\hline AGENCY NAME & $\begin{array}{l}\text { Responded to June } \\
\text { Request for } \\
\text { Information }\end{array}$ & $\begin{array}{c}\text { Responded to December } \\
\text { Survey }\end{array}$ \\
\hline - Broward County Transit & $\sqrt{ }$ & \\
\hline - Miami-Dade Transit & $\sqrt{ }$ & $\sqrt{ }$ \\
\hline - $\quad$ Palm Tran & $\sqrt{ }$ & $\sqrt{ }$ \\
\hline - LYNX & $\sqrt{ }$ & \\
\hline - Star Metro & $\sqrt{ }$ & $\sqrt{ }$ \\
\hline - $\quad$ RTS - Gainesville & $\sqrt{ }$ & $\sqrt{ }$ \\
\hline - $\quad$ PSTA & $\sqrt{ }$ & $\mathrm{v}$ \\
\hline - Key West & $\sqrt{ }$ & $\sqrt{ }$ \\
\hline - VOTRAN & $\sqrt{ }$ & \\
\hline - Lee Tran & $\sqrt{ }$ & $\sqrt{ }$ \\
\hline - Pasco County & & $\sqrt{ }$ \\
\hline - Escambia County & $\sqrt{ }$ & $\sqrt{ }$ \\
\hline - Lakeland MTD & & $\sqrt{ }$ \\
\hline - Manatee County & $\sqrt{ }$ & \\
\hline - Sarasota County & $\sqrt{ }$ & \\
\hline TOTALS & 13 & 10 \\
\hline
\end{tabular}

The following provides some of the Florida transit agency responses to specific questions included in the survey related to any rules of thumb and staffing issues. If a transit agency made general statements regarding their ratios, the researchers used the data reported in the FY 2009-2010 National Transit Database to identify the functional ratios of peak buses to number of mechanics for that system. Other relevant information provided through the initial inquiry is also added as necessary.

Three agencies provided responses to the survey question: "Does your agency use any "Tools" or "Rules of Thumb" to determine your Bus Maintenance Staffing Levels?"

- Lee County Transit (Lee Tran)

Four mechanics per shift can get the job done (repairs and PM services) for the Lee Tran fleet. When designing a work schedule for the mechanics to meet our coverage needs many things need to be considered, such as vacation and sick days. We never have more than four 
mechanics on either shift, or less than 3 mechanics, if someone calls in sick or if someone is on vacation.

- $\quad$ Miami - Dade Transit (MDT)

One Bus Maintenance Technician per 120,000 miles of services. (Author's note: In 2003, MDT's formula for indicating the number of mechanics needed was 155,400 miles of service.)

- $\quad$ Star Metro - Tallahassee

- Number of buses to mechanics (Added by author: 5.73 )

- Number of miles to bus mechanics (Added by author: 185,084 miles)

- Number of hours of operation to mechanic (Added by author: ratio not reported)

Seven agencies responded to the question "Does your agency have any other maintenance staffing concerns?"

- $\quad$ Miami - Dade Transit (MDT)

Lack of qualified applicants

- $\quad$ Palm Tran

We have increased the fleet over two years without increasing maintenance staff. (Author's note: Based on Palm Tran's NTD report, the ratio of peak bus to mechanic is 3.05, which is slightly below the average of 3.4 for the other systems reviewed. In addition, Palm Tran noted a 12 percent overtime statistic. This was the highest overtime use reported. This may be the approach Palm Tran has had to use to meet their maintenance needs).

- $\quad$ StarMetro - Tallahassee, $\mathrm{FL}$

Lack of work area for expansion

- $\quad$ City of Key West Department of Transportation

No oversight by transit operations as to direct relationship with maintenance - those functions are split out to separate management areas, makes it difficult to get work done as needed.

- $\quad$ City of Gainesville Regional Transit System (RTS)

o Bus to mechanic ratio too high (Author's note: RTS's peak bus to mechanic ratio is 4.63, which is significantly above the 3.4 bus/mechanic ratio average of the systems included in this study)

o No Materials Management

o No Shop Superintendent 
o No Maintenance Trainer

o No Maintenance Safety Supervisor

\section{- Lee County Transit (Lee Tran)}

A lead mechanic is paid $10 \%$ more when he fills in for the days his supervisor is out on regular days off, vacation, or out on sick time.

\section{- Pasco County Fleet Management}

Under staffed compared to national average (Author's note: peak bus to mechanic ratio could not be determined from Pasco County's NTD report or the information obtained through the initial inquiry).

A few observations can be made upon review of the survey responses. There were 13 systems that could be considered "responsive" to the request for information initiated in June 2010 or the survey questions (i.e., answered the majority of the questions and provided some narrative in their reply). Out of these 13 systems, 6 indicated that they are understaffed. The majority of these agencies noted budgetary limitations or hiring freezes as the primary reasons for this. Eight agencies reported the necessity of overtime led by Palm Tran which reported 12 percent overtime, followed by StarMetro and PSTA at 10 percent; RTS at 9.1 percent; Pasco County at 5 percent; ECAT at 3 percent; and MDT at 2 percent.

As would be expected, there was great variability among transit maintenance departments in the maintenance activities conducted in-house and those maintenance activities that are contracted. In general, larger transit agencies (i.e., number of vehicles and vehicle miles) tend to perform most maintenance activities in-house, including major transmission and engine rebuilds, and collision repair and other body work. Smaller agencies tend to outsource work, primarily rebuilds and major collision body work. All systems perform their own routine preventive maintenance. These are factors that could make establishing standard man-hour ratios difficult. The variation in the type of repairs made by each agency has implications both for the number of maintenance positions required and the amount of budget that must be allocated to the maintenance department.

A complete summary of the information obtained through the survey responses and the survey instrument are contained in Technical Memorandum \#1. 


\section{Chapter Four \\ Findings and Conclusions}

There are a number of factors in transit operations that make it challenging to develop simple rules of thumb or a "magic formula" that an agency might use in developing their own organizational structure and staffing levels. It is critical that the business process of organizing and staffing an agency's bus maintenance department be tailored to each individual agency. The responses from maintenance managers from across the country reflect a consistent theme. General rules of thumb can be used and can be beneficial to maintenance managers, but they must consider factors specific to their system to establish acceptable benchmarks and ratio goals.

This section summarizes myriad challenges and factors that make finding "the one size fits all" a difficult, if not a functionally unnecessary task. Yet, there are also opportunities identified including methods used by transit agencies to address staffing levels and those that have established rules of thumb or benchmarks.

\section{Contributing Factors}

As previously discussed, a number of factors and differences among the various bus maintenance departments throughout Florida and the United States contribute to the uniqueness of each agency's approach to bus maintenance and corresponding staff organization and levels. These factors include:

- $\quad$ Fleet factors

o Size of fleet

0 Vehicle manufacturers and models included in the fleet (i.e., fleet mix)

o Fleet age

o Engine and key component types

o Fuel types

- Maintenance Staff

o No common job descriptions

o Varying skill levels

o Maintenance managers control over staffing levels

- Types of service provided (e.g., fixed route, paratransit, light rail, and heavy rail)

- Type of technology deployed in buses

- Number of maintenance shifts

- Number of maintenance facilities

- In-house maintenance functions

- Contracted maintenance functions

- Availability of tools and equipment 
- Existing maintenance practices and philosophies

- Maintenance budget levels

- Operating environment

- Organizational structure

o Independent authority

o City/County governmental unit

- Negotiated work rules and union contract provisions

- Maintenance philosophy

- Availability of adequate work force

- Safety Culture and associated practices

- Attendance policies, practices, and experience

\section{Approaches to Determine Bus Mechanic Staffing Needs}

\section{Rules of Thumb}

As previously detailed, several "rules of thumb" were documented that have defined the desirable bus maintenance staffing levels for the agencies reporting. These included:

- One bus mechanic per 120,000 miles of service

- One bus mechanic per 7.62 buses

- One bus mechanic for 3 to 3.5 peak buses

- One bus mechanic for every 100,000 miles in city operations

- One bus mechanic for every 150,000 to 175,000 miles of suburban operations

- One bus mechanic for every 155,400 total vehicle miles

\section{Hours of Availability and Need Approaches}

Another, and probably more sophisticated, approach to determining required bus maintenance staffing levels incorporated a comparison of the number of available bus mechanics/technician hours and the hours required based on system characteristics and maintenance needs. These included:

- The TCRP "Public Transit Maintenance Manpower Planning" report used maintenance histories to estimate the number of hours of bus mechanic time required for key maintenance functions. This mathematical approach developed a series of normographs based on mathematical formulas that calculated corresponding man-hour requirements for each major work function. No evidence that this approach was used in the transit industry and no updates to the 1984 report could be found. 
- The 2003 USF CUTR analysis examined and evaluated the soundness of the methodology used by Miami-Dade Transit to identify bus mechanic needs. In the analysis, a methodology was developed that calculated the actual number of productive hours of a full time bus mechanic. The result was that rather than the 2080 annual hours of productive time per employee, the typical availability per mechanic was estimated to be 1,554 hours per year, after accounting for annual and sick leave, breaks, clean-up, and other non-work activities. CUTR confirmed the soundness of this model. The resultant mechanic position formula or "rule of thumb" for MDT was one mechanic for every 155,400 total vehicle miles.

- The NAFA Fleet Maintenance Association undertook a similar analysis of actual available work hours per year that resulted in the conclusion that only 80 percent of a mechanic's time (or 1,415 hours per year) is potential wrench-turning time.

- Chapel Hill Transit (CHT) undertook an evaluation of their Transit Maintenance Division to determine if their staff levels were adequate to meet vehicle service demand and maintenance requirements. The project consultant used the formulas contained in the TCRP report referenced above to determine $\mathrm{CHT}^{\prime}$ 's maintenance staffing requirements. The analysis resulted in the following standards for $\mathrm{CHT}$ maintenance positions:
o Vehicles per mechanic staff
7.05
o Vehicles per service and cleaning staff
17.92
o Vehicles per vehicle detail staff
37.00

\section{Benchmark Approach}

Yet another approach is to compare agency bus mechanic/technician staffing levels to those of peer transit agencies. This section presents two benchmark analysis approaches: one from North Carolina and the second a similar approach for Florida's transit agencies.

The North Carolina analysis was prepared by the Chapel Hill Transit Superintendant of Maintenance (subsequent to the effort described in the prior section) and provides bus to mechanic ratios for Chapel Hill, four other North Carolina transit agencies, and eight national properties. This data was all selfreported by the transit agencies.

The buses to mechanic ratios, as detailed in Table 3, are:

- Chapel Hill 7.62

- Other North Carolina agencies $\quad 5.15$

- Other National agencies 5.5 
Table 3 does reflect considerable variation between agencies. The ratio of buses to mechanic for the systems included in this table varied from 2.76 to 7.83 . Those systems with low bus to mechanic ratios include:

UNITRAN - Davis, CA

Durham Area Transit - Durham, NC

Winston-Salem Transit Authority - Winston-Salem, NC
2.76

3.50

4.33

Those systems with the highest bus to mechanic ratio include:

Athens Transit System - Athens, GA

Chapel Hill Transit - Chapel Hill, NC

Centre Area Transportation Authority - State College, PA

Capital Area Transit - Raleigh, NC

7.00

Athens/Clark County Transit System - Athens, GA

This variation could reflect differences in the amount of repairs contracted out rather than performed in house; budgetary constraints; age of fleet; or other factors. 
TABLE 3 - Chapel Hill Transit Data Gathering Summary

\begin{tabular}{|c|c|c|c|c|c|c|}
\hline City & Transit Agency & Peak Vehicles & $\begin{array}{r}\text { Full Time } \\
\text { Mechanics }\end{array}$ & Large Buses & Mechanics & $\begin{array}{r}\text { Bus to Mech } \\
\text { Ratio }\end{array}$ \\
\hline Chapel Hill & Chapel Hill Transit & 99 & 13 & 99 & 13 & 7.62 \\
\hline \multicolumn{7}{|l|}{ NC Cities } \\
\hline Durham & Durham Area Transit & 38 & 14 & 49 & 14.00 & 3.50 \\
\hline Greensboro & Greensboro Transit Authority & 39 & 9 & 57 & 9.00 & 5.78 \\
\hline Raleigh & Capital Area Transit & 58 & 10 & 70 & 10.00 & 7.00 \\
\hline \multirow[t]{2}{*}{ Winston-Salem } & Winston-Salem Transit Authority & 34 & 12 & 52 & 12.00 & 4.33 \\
\hline & System Averages (excluding CHT) & 42.25 & 11.25 & 56 & 11.25 & 5.15 \\
\hline \multicolumn{7}{|l|}{ National Cities } \\
\hline *Ann Arbor, Ml & $\begin{array}{l}\text { Ann Arbor Transportation Authority } \\
\text { (University Transit, serves U of } M \text { ) }\end{array}$ & 59 & 15 & 75 & 15.00 & 5.00 \\
\hline Gainesville, FL & $\begin{array}{l}\text { Gainesville Regional Transit System (serves } \\
\text { UF campus) }\end{array}$ & 90 & 19 & 110 & 19.00 & 5.78 \\
\hline Athens, GA & Athens Clark County Transit System & 19 & 28 & 28 & 4.00 & 7.00 \\
\hline Athens, GA & $\begin{array}{l}\text { Athens Transit System } \\
\text { (serves UGA campus) }\end{array}$ & 37 & 6 & 47 & 6.00 & 7.83 \\
\hline State College, PA & $\begin{array}{c}\text { Centre Area Transportation Authority } \\
\text { (serves PSU campus) }\end{array}$ & 48 & 7 & 52 & 7.00 & 7.40 \\
\hline Urbana, IL & $\begin{array}{l}\text { Champaign-Urbana Mass Transit System } \\
\text { (services U of I campus }\end{array}$ & 73 & 17.5 & 95 & 17.50 & 5.40 \\
\hline Davis, CA & UNITRANS (serves UC-Davis campus) & 35 & 5 & 58 & 21.00 & 2.76 \\
\hline Denver, CO & Denver RTD Group & 108 & 25 & 125 & 25.00 & 5.00 \\
\hline All Systems & All system averages (excluding CHT) & 52.33 & 13.75 & 67 & 13.13 & 5.50 \\
\hline
\end{tabular}

Source: Carl Rokos, Superintendent of Maintenance, Chapel Hill Transit, January 2010 (format modifications made by CUTR, June 2011)

*Ann Arbor Transit Authority has 12 full-time mechanics and 3 advanced vehicle electronic technicians for a total of 15 mechanics

**All mechanics are advanced technicians, but have assistance from student technicians 
A similar benchmark analysis of buses per mechanic was developed for Florida's transit agencies using self-reported mechanic levels and FY 2009-2010 National Transit Data reports. Table 4 on the following page provides the data input and results.

The ratio of available buses to mechanic for Florida's systems varied from 2.88 to 6.0, with at group average of 4.0. In general, the larger transit systems (as a function of annual vehicle miles) and those that perform a majority of preventive maintenance and repair, including rebuilds and collision repairs, are those with the better bus to mechanic ratio, with representative systems including:

$\begin{array}{ll}\text { Broward County Transit } & 2.88 \\ \text { PSTA } & 3.20 \\ \text { Miami-Dade Transit } & 3.27 \\ \text { VOTRAN } & 3.31\end{array}$

Primarily smaller systems or those that utilize contracted maintenance services are those that have higher bus to maintenance ratios. A few of the systems with higher ratios include:

$\begin{array}{ll}\text { StarMetro } & 6.00 \\ \text { Gainesville RTS } & 5.53 \\ \text { Lee Tran } & 4.36 \\ \text { LYNX } & 4.36\end{array}$

The inclusion of LYNX in the second group of systems with bus to mechanic ratios in excess of the average for all systems is curious. However, as mentioned throughout this discussion, there are many critical factors that are weighed when determining an adequate number of mechanics to service public transit vehicles. In the absence of evidence to suggest this ratio is inadequate, it is difficult to make a statement about LYNX when comparing them to the systems presented. Adequate staffing could be reflected in positive statistics related to miles between roadcalls or "mean distance between failures," acceptable statistics on the number of days vehicles are out of service while being repaired, and the agency's ability to conduct scheduled preventive maintenance activities in a timely manner. 
Florida Bus Maintenance Staffing Practices - Final Report

TABLE 4

Florida Transit System Mechanic Staffing Ratios

\begin{tabular}{|c|c|c|c|c|c|c|c|c|c|c|}
\hline \multirow[b]{2}{*}{ FY 2009-2010 NTD Data } & \multirow{2}{*}{$\begin{array}{c}\begin{array}{c}\text { Self } \\
\text { Reported }\end{array} \\
\text { Number of } \\
\text { Mechanics } \\
\end{array}$} & \multicolumn{5}{|c|}{ FY 2009-2010 NTD Report } & \multicolumn{4}{|c|}{ Ratios } \\
\hline & & Peak Buses & $\begin{array}{c}\text { Available } \\
\text { Buses }\end{array}$ & $\begin{array}{c}\text { Annual } \\
\text { Passenger } \\
\text { Trips } \\
\end{array}$ & $\begin{array}{c}\text { Annual } \\
\text { Vehicle } \\
\text { Hours }\end{array}$ & $\begin{array}{c}\text { Annual } \\
\text { Vehicle } \\
\text { Miles }\end{array}$ & $\begin{array}{c}\text { Peak Bus / } \\
\text { Mechanic } \\
\text { (E/D) } \\
\end{array}$ & $\begin{array}{l}\text { Available } \\
\text { Buses / } \\
\text { Mechanic } \\
\text { (F/D) }\end{array}$ & $\begin{array}{l}\text { Vehicle } \\
\text { Hours / } \\
\text { Mechanic } \\
\text { (H/D) }\end{array}$ & $\begin{array}{c}\text { Vehicle Mile } \\
\text { / Mechanic } \\
\text { (I/D) }\end{array}$ \\
\hline Broward County Transit & 101 & 240 & 291 & $36,804,682$ & $1,079,595$ & $15,544,431$ & 2.38 & 2.88 & 10,689 & 153,905 \\
\hline Miami-Dade Transit & 264 & 716 & 863 & $75,608,000$ & $2,874,681$ & $37,092,499$ & 2.71 & 3.27 & 10,889 & 140,502 \\
\hline Palm Tran & 40 & 122 & 154 & $10,026,046$ & 462,886 & $7,535,471$ & 3.05 & 3.85 & 11,572 & 188,387 \\
\hline LYNX & 66 & 234 & 288 & $23,747,795$ & $1,107,263$ & $16,215,911$ & 3.55 & 4.36 & 16,777 & 245,696 \\
\hline Star Metro & 11 & 63 & 66 & $4,409,041$ & 185,332 & $2,035,927$ & 5.73 & 6.00 & 16,848 & 185,084 \\
\hline RTS - Gainesville & 19 & 88 & 105 & $8,939,980$ & 258,820 & $2,963,463$ & 4.63 & 5.53 & 13,622 & 155,972 \\
\hline PSTA & 64 & 170 & 205 & $11,865,520$ & 650,622 & 9,922,956 & 2.66 & 3.20 & 10,166 & 155,046 \\
\hline VOTRAN & 16 & 46 & 53 & $3,071,247$ & 164,760 & $2,645,438$ & 2.88 & 3.31 & 10,298 & 165,340 \\
\hline Lee Tran & 14 & 48 & 61 & $3,040,037$ & 193,455 & $3,184,588$ & 3.43 & 4.36 & 13,818 & 227,471 \\
\hline Pasco County & NA & 16 & 29 & 926,076 & 69,900 & $1,194,100$ & & & & \\
\hline Escambia County & NA & 32 & 39 & $1,131,853$ & 105,797 & $1,391,293$ & & & & \\
\hline Lakeland MTD & NA & 24 & 41 & $1,450,988$ & 80,871 & $1,294,963$ & & & & \\
\hline Manatee County & NA & 19 & 31 & $1,403,104$ & 89,982 & $1,365,611$ & & & & \\
\hline Sarasota County & 17 & 44 & 61 & $2,551,650$ & 199,268 & $3,010,040$ & 2.59 & 3.59 & 11,722 & 177,061 \\
\hline & & & & & & AVERAGES & 3.4 & 4.0 & 12,640 & 179,446 \\
\hline
\end{tabular}

Sources: National Transit Database, FY 2009 - 2010

Center for Urban Transportation Research, 2011 


\section{Accomplishments}

In summary, the "Florida Bus Maintenance Staff Practices" project:

- Uncovered and documented rules of thumb that have been and are currently used by maintenance managers across the country;

- Identified some approaches used by transit systems to evaluate their staffing levels and conduct analysis to determine the correct staffing ratios for their department; and

- Calculated benchmark ratios for 10 Florida transit systems, based on 2009-2010 National Transit Database reports.

Finally, this research project compiled and documented a wealth of information on the current bus maintenance staffing practices for Florida's fixed route transit agencies. This information is provided in the two technical memorandums developed as part of this research project. These documents include the literature review; a discussion of and summary of relevant materials collected from Florida transit agencies, including position descriptions; the responses to TBR's Bus Fleet Managers' listserv and associated discussion; and the responses to the survey of the Florida bus maintenance departments and corresponding summary. The reader should refer to these technical memorandums to access this valuable information. Transit maintenance managers can benefit from becoming familiar with the approaches used by their peer agencies that are recorded in these resources. 


\section{References}

National Center for Transit Research. "Florida Bus Maintenance Staffing Practices, Technical

Memorandum \#1," Center for Urban Transportation Research, University of South Florida, June, 2011

National Center for Transit Research. "Florida Bus Maintenance Staffing Practices, Technical

Memorandum \#2," Center for Urban Transportation Research, University of South Florida, June, 2011

National Center for Transit Research. "Mechanic Manpower Analysis for Miami-Dade Transit," Center for Urban Transportation Research, University of South Florida, June, 2003.

Transportation Research Board. "Public Transit Bus Maintenance Manpower Planning," Drake, R.W. and Carter, D.W., Report 10, National Cooperative Transit Research and Development Program, December, 1984.

Transportation Research Board. "Evaluation of Maintenance Manpower Utilization," Drake, R.W. and Carter, D.W., Transportation Research Record Issue No. 1019, pages 49-62, 1985.

Transportation Research Board. "Evaluation of Bus Maintenance Operations," Drake, R.W. and Carter, D.W., Transportation Research Record Issue No. 1019, pages 77-84, 1985.

NAFA Fleet Maintenance Association. "Fleet Maintenance Operations Guide," Chapter 7 - Maintenance Staffing, pages 409-424, June 2009.

Federal Transit Administration. "Characteristics of Urban Transportation Systems," Cambridge Systematics, Inc. et al, Revised Edition, September 1992.

Town of Chapel Hill, North Carolina. "Town of Chapel Hill Transit Maintenance Staff Analysis," Parsons Brinkerhoff, Inc. 2003. 